\title{
Learning Mathematical Modelling: What Advantages a Visual-Formed Problem Against Problem-Solving Skills of Junior High School Students?
}

\author{
SS Wati ${ }^{1,}$ Darmawijoyo ${ }^{1, *}$ Hapizah $^{1}$ \\ ${ }^{I}$ Mathematics Education Department, Sriwijaya University \\ *Corresponding author. Email: darmawijoyo@unsri.ac.id
}

\begin{abstract}
The purpose of this research is to describe the mathematical problem-solving skills of Junior High School students through visual question-based mathematical modeling learning. This was descriptive research using a qualitative approach. The subjects were students grade VII/2 of SMP N 6 Indralaya Utara. In the data collection techniques, posttest and interviews were used to see the students' mathematical problem-solving skills. Based on the findings, the percentage of indicator occurrences of understanding the problem was $76,84 \%$, planning the completion strategy was $38,60 \%$, implementing the completion strategy was $49,12 \%$, and reviewing was $23,68 \%$.
\end{abstract}

Keywords: Mathematical modelling, visual-formed problem, problem-solving skills.

\section{INTRODUCTION}

Students need to master problem-solving skills. This can be seen from the 21st-century students' demands, namely 4C (Communication, Collaboration, Critical Thinking, and Problem Solving, Creativity and Innovation), in which one of them is Critical Thinking and Problem Solving. Besides, in the Content Standards in Regulation of the Minister of Education and Culture (Permendikbud) No. 64 of 2013 about curriculum, problem-solving is also included in the competencies that the students should possess [1]. Problem-solving as a process planned to solve a non-routine problem to obtain and requires prior experience and skills [2]. Therefore, mathematical problem solving is a planned process to get a solution to a mathematical problem that cannot be obtained directly and requires knowledge, experience, and apply the skills learned in the classroom.

Absolutely, with the implementation of the 2017 Revised 2013 Curriculum, it is expected that students can master good mathematical problem-solving skills. However, what happened was that the mathematical problem-solving skills of Junior High School students in Indonesia were not in accordance with what was expected. This could be seen from the results of PISA Indonesia 2018, where for PISA questions level 5 or higher in the mathematical skills, there were only $1 \%$ of
Indonesian students achieving mastery in modeling complex situations mathematically, while the average $O E C D$ was $11 \%$. To which level 5 or higher was a matter of problem-solving and reasoning [3]. Some of the findings regarding the students' difficulties in working on PISA questions were located in: (1) understanding the meaning of the question; (2) linking the real-life aspects into the mathematical problems (models); (3) performing the mathematical operations; (4) interpreting the results of solving mathematics to the real-world problems [4]. Moreover, students experienced difficulties in determining data related to the questions, connecting data across the representations or sources, and estimating data, not in the questions [5].

As previously explained, many factors resulted in Indonesian students unable to work on PISA questions at a high level, which required high problem-solving competencies. One of the factors was learning content. It is currently very rare to use contextual problems, namely problems directly related to the students themselves' phenomena. If a problem like this is given to them, then mathematical modeling learning is very suitable since it fulfills its characteristics. Modeling makes an essential contribution to building students' problem-solving skills [6]. Mathematical modeling learning can improve the students' skills to solve problems, especially real-world problems [7]. Besides, the mathematical problem solving 
and mathematical modeling have a close relationship in terms of the problem-solving stages according to Polya (understanding the problem, making the plan, implementing the plan, and reviewing) [8], with the mathematical modeling process (understanding the problem, building the model, solving the model, interpreting and validating the model).

Many studies link problem-solving skills with mathematical modeling approaches [9]. Nonetheless, very few studies have linked problem-solving skills to a visual question-based mathematical modeling approach. The selection of context for visual questions was inspired by Hoogland's findings, which revealed that the students preferred visual questions to text questions [10]. Reducing the words and adding pictures to the questions given will be the optimal combination of the students' results [10]. In the research carried out by Hoogland et al., they used the story questions transformed into the visual (image) questions. Therefore, the researchers would describe students' mathematical problem-solving skills grade VII/2 of SMP N 6 Indralaya Utara, which previously had done the visual question-based mathematical modeling learning on the inverse proportion material.

\section{METHOD}

The purpose of this research was to describe the mathematical problem-solving skills of Junior High School students through visual question-based mathematical modeling learning. Accordingly, this type of research was a research study using a qualitative approach. This research focused on students' mathematical problem-solving skills grade VII/2 of SMP $\mathrm{N} 6$ Indralaya Utara through visual question-based mathematical modeling learning. The subjects were 19 students grade VII/2 of SMP N 6 Indralaya Utara. This research was conducted in the even semester of the 2019/2020 school year.

The indicators of the mathematical problem-solving skills used in this research are as follows.

Table 1. Indicators of mathematical problem-solving skills.

\begin{tabular}{|l|l|}
\hline Indicators & Descriptor \\
\hline $\begin{array}{l}\text { Understanding } \\
\text { the problem }\end{array}$ & $\begin{array}{l}\text { - Writing down the known data in } \\
\text { the question. } \\
\text { - Writing down the problems in } \\
\text { the question. }\end{array}$ \\
\hline $\begin{array}{l}\text { Planning the } \\
\text { completion } \\
\text { strategy }\end{array}$ & $\begin{array}{l}\text { Designing a mathematical model } \\
\text { by connecting any required data } \\
\text { using mathematical operations. }\end{array}$ \\
\hline $\begin{array}{l}\text { Implementing } \\
\text { the completion } \\
\text { strategy }\end{array}$ & $\begin{array}{l}\text { Performing all mathematical } \\
\text { calculations from the model } \\
\text { obtained. }\end{array}$ \\
\hline
\end{tabular}

\begin{tabular}{|l|l|}
\hline Reviewing & $\begin{array}{l}\text { Reviewing the results obtained by } \\
\text { being able to make conclusions in } \\
\text { accordance with the problem. }\end{array}$ \\
\hline
\end{tabular}

\subsection{First Meeting}

The first meeting was held on 12 March 2020. The activity carried out was implementing the pre-test, which aimed to find out how the students' initial skills in the inverse proportion material they had learned previously and to divide them into four discussion groups used when doing the mathematical modeling learning, based on the pre-test results.

\subsection{Second Meeting}

The second meeting was held on 16 March 2020. The activity carried out was mathematical modeling learning using the visual-formed problem. Each group was given a visual-formed problem accompanied by a poster containing tables and pictures and a mathematical modeling Students' Worksheet (LKPD) containing questions that guided them to solve the problems given. Then, the teacher appointed the representatives from the two groups to present the group's answers in front of the class, and other groups were asked to respond.



Figure 1. Visual-formed problem.

Figure 1 is the development of a visual-formed problem used as a mathematical modeling learning in this research. The development of these questions was carried out by developing multiple-choice questions in Junior High School National Examination (UN) on the inverse proportion subject into mathematical modeling text questions by adding the context of the order for sports uniforms. The mathematical modeling questions that had been formed were visualized into the modeling problems as a combination of pictures and a few words, without changing the meaning of the previous mathematical modeling text problems. 


\subsection{The Third Meeting}

Was held on 18 March 2020. The post-test and interviews were conducted. The post-test was aimed to see the students' mathematical problem-solving skills in solving the mathematical modeling questions with the inverse proportion material. The post-test question consisted of a mathematical modeling text question in the form of a description of the inverse proportion material done individually. The answer sheet was assessed based on the mathematical problem-solving skills scoring rubric after the test was carried out. The interviews aimed to find out the students' mathematical problem-solving skills more deeply and to find out how they perceived the visual-formed problem given. The following is a table of scoring guidelines for mathematical problem-solving skills.

Table 2. Scoring Guidelines for Mathematical Problem Solving Skills

\begin{tabular}{|c|c|c|c|}
\hline Indicator & Descriptor & Answer Criteria & Score \\
\hline $\begin{array}{l}\text { Understanding } \\
\text { the problem }\end{array}$ & $\begin{array}{l}\text { - Writing down the } \\
\text { known data in the } \\
\text { question. } \\
\text { - Writing down the } \\
\text { problems in the } \\
\text { question. }\end{array}$ & $\begin{array}{l}\text { - No answer } \\
\text { - Writing the known data in the question, but it is still incorrect. } \\
\text { - Writing the known data in the question, but it is still incomplete. } \\
\text { - No answer } \\
\text { - Writing down the problems in the question, but it is still incorrect. } \\
\text { - Writing down the problems in the question correctly. }\end{array}$ & $\begin{array}{l}\text { - } 0 \\
\text { - } 1 \\
\text { - } 2 \\
\text { - } 3 \\
\text { - } 1 \\
\text { - } 2\end{array}$ \\
\hline $\begin{array}{l}\text { Planning the } \\
\text { completion } \\
\text { strategy }\end{array}$ & $\begin{array}{l}\text { Designing a } \\
\text { mathematical model } \\
\text { by connecting any } \\
\text { required data using } \\
\text { mathematical } \\
\text { operations. }\end{array}$ & $\begin{array}{l}\text { - No answer } \\
\text { - Designing a mathematical model by connecting any required } \\
\text { - data using mathematical operations but it is still incorrect. } \\
\text { data using mathematical operations but it is still incomplete. } \\
\text { - Designing a mathematical model by connecting any required } \\
\text { data using mathematical operations correctly and completely }\end{array}$ & $\begin{array}{l}\cdot 0 \\
\cdot 1\end{array}$ \\
\hline $\begin{array}{l}\text { Implementing } \\
\text { the } \\
\text { completion } \\
\text { strategy }\end{array}$ & $\begin{array}{l}\text { Performing all } \\
\text { mathematical } \\
\text { calculations from the } \\
\text { model obtained. }\end{array}$ & $\begin{array}{l}\text { - No answer } \\
\text { - Performing all mathematical calculations from the model } \\
\text { obtained, but it is still incorrect. } \\
\text { - Performing all mathematical calculations from the model } \\
\text { obtained, but it is still incomplete. } \\
\text { - Performing all mathematical calculations from the model } \\
\text { obtained correctly and completely. }\end{array}$ & $\begin{array}{l}\cdot 0 \\
\cdot 1\end{array}$ \\
\hline Reviewing & $\begin{array}{l}\text { conclusions in } \\
\text { accordance with the } \\
\text { problem. }\end{array}$ & $\begin{array}{l}\text { - No answer } \\
\text { - Reviewing the results obtained by being able to make conclusions } \\
\text { in accordance with the problem, } \\
\text { - Reviewing the results obtained by being able to make conclusions } \\
\text { in accordance with the problem correctly. }\end{array}$ & $\begin{array}{l}\cdot 0 \\
-1\end{array}$ \\
\hline
\end{tabular}


The data collection techniques in this research were tests and interviews. The post-test in this research aimed to see the student's mathematical problem-solving skills. In contrast, the interviews aimed to find out the students' mathematical problem-solving skills more deeply and to find out how they perceived the visual-formed problem given.

The data analysis technique in this research was by correcting the post-test answers, giving a score according to the scoring guidelines adjusted to the indicators of the mathematical problem-solving skills, then determining the post-test score and dividing the mathematical problem-solving skills into the following categories: poor, fair, adequate, good, excellent. On the other hand, the interview data were analyzed by transcribing the interviews into written form. Subsequently, they were reduced, selected, and summarized according to what data were desired.

\section{RESULTS AND DISCUSSION}

\subsection{Results}

The following is the post-test results regarding students' mathematical problem-solving skills grade VII/2 of SMP Indralaya Utara in this research.

Table 3. Categories of Students' Mathematical Problem Solving Skills

\begin{tabular}{|c|c|c|c|}
\hline $\begin{array}{c}\text { Student } \\
\text { Score Range }\end{array}$ & Frequency & Percentage & Category \\
\hline $80 \leq T \leq 100$ & 3 & $16 \%$ & Excellent \\
\hline $60 \leq T<80$ & 2 & $11 \%$ & Good \\
\hline $40 \leq T<60$ & 9 & $47 \%$ & Adequate \\
\hline $20 \leq T<40$ & 5 & $21 \%$ & Fair \\
\hline $0 \leq T<20$ & 1 & $5 \%$ & Poor \\
\hline Average & 19 & & Adequate \\
\hline Score & \multicolumn{4}{|c|}{51,15} & \\
\hline
\end{tabular}

Table 4. Percentage of indicator of Students' Mathematical Problem Solving Skills

\begin{tabular}{|l|c|}
\hline Indicator & Percentage \\
\hline Understanding the problem & $\mathbf{7 6 , 8 4} \%$ \\
\hline Planning the completion strategy & $38,60 \%$ \\
\hline Implementing the completion strategy & $49,12 \%$ \\
\hline Reviewing & $23,68 \%$ \\
\hline
\end{tabular}

Based on the post-test results, several students who had good communication skills were determined to be the subjects of the interviews related to the students' mathematical problem-solving skills and their views on the mathematical modeling learning using the visualformed problems.

\subsubsection{Subject of $C P$}



Figure 2. The results of the student answer in the excellent category.

When viewed from the $\mathrm{CP}$ answer sheet, $\mathrm{CP}$ was able to apply the method used when solving the visual-formed problem in Student's Worksheet (LKPD) to answer the post-test question. The following is the final answer in the Student's Worksheet (LKPD).

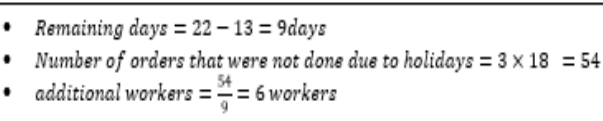

Figure 3. The following is the final answer in the Student's Worksheet (LKPD).

Consequently, the learning that had been carried out before affected CP's way of thinking in solving a similar inverse proportion question. In this case, it can be seen in CP's answer sheet; it was used simple calculations in accordance with what $\mathrm{CP}$ understood and was not fixated on using the inverse proportion formula.

CP's answer would be analyzed based on the indicators of mathematical problem-solving skills. In the indicator of understanding the problem, it appears that $\mathrm{CP}$ was able to determine (Problem to find), namely in terms of finding known data and what to look for, so CP got a score of 5. The indicator determined that CP's completion strategy was able to make a mathematical model, namely: the relationship between the surviving and resigning workers, the number of days and workers, and the number of works and workers. It was just that $\mathrm{CP}$ did not use a variable in the form of a letter for that. The model made by CP could only apply to this problem. CP also did not write the model coherently and did not write the model formed to get 100 , but in the interview, CP explained the process to get 100 .

Nevertheless, what stood out here was that $\mathrm{CP}$ was able to use the experience gained during the learning using Students' Worksheet (LKPD), so CP got a score of 2. In implementing the plan, $\mathrm{CP}$ was able to do well; it can be seen that $\mathrm{CP}$ was being to do all the calculations 
correctly, so $\mathrm{CP}$ got a score of 3 . In the reviewing stage, $\mathrm{CP}$ was inaccurate in concluding in accordance with the problem, so $\mathrm{CP}$ got a score of 1 . The following is the interview conducted with $\mathrm{CP}$.

$\mathrm{P} \quad$ : "How do you get it (pointing to CP's answer)?"

CP : "24 workers within 25 days, so 24 workers minus four resigning workers."

$\mathrm{P} \quad$ : "And then?"

CP :" $25 \times$ x 4 is $100 "$

$\mathrm{P} \quad$ : "So, what is 100 ?"

CP : "The number of works not done by the workers."

$\mathrm{P} \quad$ : "Then, what's next?"

CP :"100 is divided by the rest of the workers."

$\mathrm{P} \quad$ : "So, how many additional days are needed?"

CP :"'5 days."

$\mathrm{P} \quad$ :'I want to ask about the learning we had done in the previous meeting. In your opinion, did the mathematical learning that I taught you yesterday require you to memorize formula in the process? If so, what was the formula?"

CP : "No. Just directly divide, subtract, and multiply."

P : : Okay. In your opinion, did the mathematical learning that I taught yesterday make you happy to learn in class? Why? "

CP :"Yes, because you gave me completion steps and a poster/picture."

P : "Do you think that the mathematics that I teach is more interesting than the book's mathematics?"

CP : "Yes, because it is simple and has pictures."

P :"Should mathematical learning be added if they are taught just like what I do? For example, in the form of questions with pictures, not only texts?"

CP : "Yes, because I am not good at mathematics."

P :" Do the pictures or posters on mathematical learning help you work on the question given?"

CP : "Yes, since it is step by step, and there is an answer in the table."

Based on the interview results, $\mathrm{CP}$ could explain the answer CP wrote in the answer sheet. As a consequence, $\mathrm{CP}$ got excellent results. $\mathrm{CP}$ was a student who felt interested in mathematical modeling learning using the visual-formed problem, so $\mathrm{CP}$ was able to apply the strategy used in answering Student's Worksheet (LKPD) to solve similar problems. CP also noted that Student's Worksheet (LKPD) and posters/pictures used help the students solve the questions.

\subsubsection{Subject of $Y P$}

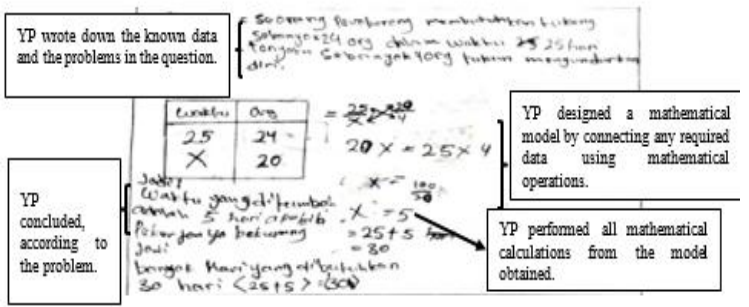

Figure 4. The results of the student answer in the excellent category

If seen from YP's answer sheet, YP was able to apply the method used when solving the visualformed problems in Student's Worksheet (LKPD) to answer the post-test question. It seems that YP was able to define a variable with $x$ as the additional workers it should look for. To find $x$, YP used the strategy obtained during the learning using Student's Worksheet (LKPD), where YP looked for the number of works not done by multiplying the number of days by the remaining workers. The number of works not done was divided by the remaining workers, so $x$ was obtained as the additional workers.

Then, YP's answer would be analyzed based on the indicators of mathematical problem-solving skills. In the indicator of understanding the problem, it appears that YP was able to determine (Problem to find), namely finding known data, but there were still data that YP had not written down. YP also understood what was looking for, but he failed writing it down. It can be seen from the conclusion that YP made, so YP got a score of 3. In the indicator of planning the completion strategy, YP was able to design a mathematical model, namely: the relationship between the surviving workers and additional days, the number of days, and resigning workers $(20 x=25 \times 4)$. YP was also able to use a variable in the form of a letter, then YP wrote the model coherently, so YP got a 3. In the indicator of implementing the plan, YP was able to do well. It can be seen that YP was able to do all the calculations correctly, so YP got a score of 3 . In the reviewing stage, YP was able to conclude in accordance with the problem, so YP got a score of 2. The following is the interview with YP.

P : "Please explain your answer." 
YP :"A contractor needs 24 workers within 25 days, but four workers resign. $\frac{25}{x}$ cross-multiplied by

$$
\text { P : "How can you get } 20 \text { ?" }
$$

YP : "From this (showing the table he created)."

$\mathrm{P} \quad$ : "What is $x$ ?"

YP : "The additional workers."

P : "Okay. Here I want to ask about the learning we had done in the previous meeting. In your opinion, did the mathematical learning that I taught you yesterday require you to memorize formula in the process? If so, what was the formula?"

YP : "Yes, I used mathematical formulas such as division, subtraction, and multiplication."

P : "So, it only used division, subtraction, and multiplication. In your opinion, did the mathematical learning that I taught yesterday make you happy to learn in class? Why? "

YP : "Yes, because it is exciting to learn while playing."

P : :Do you think that the mathematics that I teach is more interesting than the book's mathematics?"

YP : "Yes, because it can add our knowledge, and there are pictures."

P : : "Do you want mathematical learning to be taught just like what I do? Why?"

YP : "Yes, it can make it easier for us to answer the question."

P : "Do the pictures or posters on mathematics learning help you work on the question given?"

YP : "Yes. It makes it easier for us to calculate and get the answer."

Based on the interview results, YP was able to explain the answer YP wrote in the answer sheet. Consequently, YP got excellent results. YP was a student who felt interested in the mathematical modeling learning using the visual -formed problems, so YP was able to apply the strategy used in answering Student's Worksheet (LKPD)to solve similar problems. YP also said that Student's Worksheet (LKPD) and posters used helped YP solve the question.

\subsection{Discussion}

This research aimed to determine the students' mathematical problem-solving skills at SMP Negeri 6 Indralaya Utara in the inverse proportion material revealed by their post-test results after the visual question-based mathematical modeling learning was applied. The results portrayed that the percentage of each indicator of the students' mathematical problem-solving skills was as follows: The indicator of understanding the problem was $76,84 \%$, planning the completion strategy was $38,60 \%$, implementing the completion strategy was $49,12 \%$, and reviewing was $23,68 \%$. In this case, the percentage of each indicator of the students' mathematical problem-solving skills was said to be satisfactory, especially in the indicator of understanding the problem that almost all students were able to do well.

Furthermore, learning using visual question-based mathematical modeling Students' Worksheet (LKPD) can be said to have contributed to the students' mathematical problem-solving skills. This can be seen from their answers that used the stages in accordance with those in Students' Worksheet (LKPD) to visualize the mathematical modeling problem to obtain the posttest question solutions, such as, they tried to identify/understand the problem first and write it down, then plan a strategy to solve/design a model, implement the strategy to solve/complete the model, and review. The roles of visualization in solving problems were: helping students understand problems, as a substitute for calculations, checking solutions, changing problems to a mathematical form [11]. Next, reducing words and adding images to the questions given would be an optimal combination of the student outcomes [10].

From student work, we can see that the developed students' worksheet could develop students' strategies to solve the inverse proportion without using the formula as they did earlier.

\section{CONCLUSIONS}

Based on the discussion above, it can be concluded that visual-formed problem in mathematical modelling learning helped students solve problems since this learning made it easier for them to understand the problems. Secondly, visual question-based mathematical modelling learning made students more interested in participating in learning and helped them solve them.

\section{ACKNOWLEDGMENTS}

The writers would like to show gratitude to Elika Kurniadi, M. Sc. and Dwi Ratna, S. Pd. As the validators.

\section{REFERENCES}

[1] Kemendikbud, Peraturan Menteri Pendidikan dan Kebudayaan Republik Indonesia Nomor 21 Tahun 2016, Jakarta : Kemendikbud, 2016

[2] Saad N. S. dan S. A. Ghani, Teaching Mathematics in Secondary Schools: Theories and Practices, Perak: Universiti Pendidikan Sultan Idris Malaysia, 2008

[3] OECD, PISA 2018 Assessment and Analytical Framework, Paris : OECD Publishing, 2019

[4] Simalango, M. M., Darmawijoyo, D., \& Aisyah, N, kesulitan siswa dalam menyelesaikan soal-soal pisa 
pada konten change and relationship level 4, 5, dan 6 di smp n 1 indralaya, J. Pend. Mat Unsri, vol. 12, 2018, pp. 43-58. DOI : 10.22342

[5] Wijaya, A., van den Heuvel-Panhuizen, M., Doorman, M., \& Robitzsch, A, Difficulties in solving context-based PISA mathematics tasks: An analysis of students' errors, The Mathematics Enthusiast, ISSN 1551-3440 vol. 11, 2014, pp. 555584.

[6] Özdemir, E., \& Üzel, D, A case study on teacher instructional practices in mathematical modelling, $\mathrm{J}$ Res Math Educ, vol. 3, 2012, pp.1-14.

[7] R. Lesh, H. Doerr, Beyond Constructivism, Models and Modeling Perspectives on Mathematics Problem Solving, Learning, and Teaching, Lawrence Erlbaum. Mahwah, NJ. Book Reviews. Ernst von Glasersfeld, Amherst, MA (USA), vol. 35, 2003, pp. 6. Available: http://subs.emis.de/journals/ZDM/zdm036r3.pdf

[8] Polya, G, How to Solve it : A New Aspect of Mathematical Method, Princeton : Princeton University Press, 1973

[9] Yoga.P, Darmawijoyo \& Indaryanti, Pengaruh Pembelajaran Matematika Modelling Terhadap Kemampuan Memahami Soal Cerita Siswa Sekolah Menengah Pertama, Skripsi: Universitas Sriwijaya, 2018

[10] K. Hoogland, B. Pepin, J.D. Koning, A. Bakker, K. Gravemeijer, Word problems versus image-rich problems: an analysis of effects of task characteristics on students' performance on contextual mathematics problems, Research in Mathematics Education, vol. 20, 2018, pp. 37-52. DOI:

https://doi.org/10.1080/14794802.2017.1413414

[11] Presmeg, N. C, Visualisation in high school mathematics. For the learning of mathematics, vol. 6, 1993, pp. 42-46

DOI:

https://doi.org/10.1007/978-3-030-15789-0.161 